Marijke van der Wal*

\title{
The black box of delegated writing: Early Modern scribes and female literacy in The Netherlands
}

https://doi.org/10.1515/jhsl-2020-0018

Received July 1, 2020; accepted November 1, 2020

Abstract: Apart from literacy rates and reading and writing acquisition, the actual writing practices of the past, which include the phenomenon of delegated writing, belong to a history of literacy. Delegated writing occurred when illiterate or partly literate individuals wanted to keep in contact with relatives at a distance and had to rely on the assistance of professional or social scribes. The details of this process and the role played by the sender of a letter and its actual, usually unknown, scribe often remain unclear, although different scenarios may be assumed. Cultural historian Lyons explored scenarios for delegated writing in France, Italy and Spain in the nineteenth and early twentieth centuries, focusing on the writing of ordinary people during the First World War and in the age of mass migration. For the Dutch language area, we have the opportunity to delve further back in time by exploring the late-seventeenth-century part of the Letters as Loot ( $L A L)$ corpus. This corpus previously allowed us to establish linguistic differences between autographs and non-autographs. For a detailed view of the delegated writing process, however, the $L A L$ corpus also provides us with instances of two types of letters written by the same, identified, female scribes: their own letters and the letters they wrote for others. A comparative analysis of these different letters will be shown to contribute to opening the black box of Early Modern delegated writing.

Keywords: autographs/non-autographs; delegated writing; epistolary formulae; literacy; social writers

\section{The phenomenon of delegated writing}

Historical linguists and cultural historians share their research interest in the history of literacy, and this research focuses on literacy rates, reading and writing acquisition and their geographical and chronological differences. In the Early and

*Corresponding author: Marijke van der Wal, Leiden University Centre for Linguistics, Leiden, The Netherlands, E-mail: m.j.van.der.wal@hum.leidenuniv.nl 
Late Modern period, literacy rates differed considerably across Europe: higher literacy rates were found in the northern Netherlands and the Scandinavian regions, for instance, than in the southern Netherlands and Romance countries, and the literacy rate for men was generally higher than that for women (cf. Graff 1987: 173-248; Houston 2013: 144-146, 169; van der Wal 2006). The late nineteenth and early twentieth centuries saw a writing revolution generated by the First World War and mass migration across the oceans, which, according to Lyons (2014: 250-251), led to "a massive outpouring of letter-writing amongst people who were barely literate and totally unaccustomed to handling a pen”. Illiterate or partly literate individuals who wanted to keep in contact with relatives at a distance had to rely on the assistance of professional or social scribes. The details of this process of socalled delegated writing often remain unclear, although different scenarios may be assumed. Did the scribe complete a particular format, did the sender of a letter dictate the contents or did they collaborate in some way? The question may also arise whether the delegated writing process differed depending on the assistance of either a professional scribe or a relative, friend or neighbour who functioned as a social writer. ${ }^{1}$

Having explored scenarios for delegated writing in France, Italy and Spain, focusing on the writing of ordinary people (letters of migrants to North America and soldiers' correspondence during the First World War), cultural historian Lyons stresses the fragmentary evidence so far and the need to accumulate "randomly occurring scraps of data" (Lyons 2013, 2014: 245). What I intend to do in the present article is to turn to a linguistic approach of another language area and another earlier - time period in order to reveal possible scenarios of delegated writing. For the Dutch language area, I have the opportunity to delve further back in time by examining the late-seventeenth-century part of the Letters as Loot (LAL) corpus, compiled at Leiden University, which comprises private letters, sent by both men and women from various social ranks. ${ }^{2}$ These letters were confiscated by the English during periods of war and survived to become a treasure trove for present-day historical sociolinguists, as I will discuss in Section 2. Being able to distinguish between letters self-written by the sender and non-autographs was crucial for determining the language use of people of different genders, ages and social classes (Rutten and van der Wal 2014: 1-18). Our quantitative research also

\footnotetext{
1 I note that my concept of professional writer differs from Lyons (2014), who characterises the professional writer as a person "working from a stall in a public place" and considers the local notable as a social writer. For me both are professional writers.

2 The lemmatised and POS-tagged $L A L$ corpus of more than 1,000 letters is available as an internet application at http://brievenalsbuit.ivdnt.org, comprising photos, transcriptions and metadata, and provided with extensive search facilities.
} 
allowed us to establish linguistic differences between autographs and nonautographs, as will be shown in Section 3. Apart from this result, qualitative research on particular letters offers a more detailed view of the delegated writing process, as will become clear in Section 4. It is fascinating to discover instances of two types of letters written by the same, identified, female scribes: their own letters and their delegated ones. Despite their generally lower literacy rate, women appear to have acted as delegated writers for others. In Sections 5 and 6, I will present six cases of such female letter writers. Examining and comparing their two types of letters, will reveal characteristics of Early Modern delegated writing. Finally, in Section 7 the results will be discussed and conclusions will be drawn.

\section{Letters as loot: evidence of literacy, semi-literacy and illiteracy}

Although in Early and Late Modern times many Dutch private letters must have been exchanged by people from all social ranks, relatively few survived. Private letters from women in general and from both men and women of lower and middle ranks were available only in very small numbers, scattered over various archives in the Netherlands (cf. van der Wal 2006). The rediscovery of an impressive collection of Dutch private letters, kept in the National Archives (Kew/London UK), however, opened up entirely new perspectives. These letters dating from the seventeenth, eighteenth and early nineteenth centuries, are among the papers, both commercial and private, that were confiscated from ships taken by the English fleet and by private ships (privateers) during the frequent warfare between England and the Netherlands. About 40,000 Dutch letters, including 15,000 private ones, sent from the Netherlands to, for example, Asia, Africa, the Caribbean region and vice versa, miraculously survived (cf. van der Wal et al. 2012). As the confiscated letters preserve the written language of thousands of different writers, men and women, from different social classes, age groups and regions, they form an excellent basis for an investigation of everyday written communication in the past and its variation and change (cf. Elspaß 2012a; Schneider 2013). The first extensive sociolinguistic analysis of these Dutch letters was conducted in the Brieven als Buit/Letters as Loot research programme (2008-2013), funded by the Netherlands Organisation for Scientific Research and directed by Marijke van der Wal at Leiden University (Rutten and van der Wal 2014: 1-18; van der Wal and Rutten 2016). This research concentrated on a selection of about one thousand Dutch private letters from the late seventeenth and late eighteenth centuries, written by more than 700 different letter writers, and this selection was made available as the $L A L$ corpus by the end of the 
research project (see footnote 2). In order to achieve reliable historical sociolinguistic results, the historical context of literacy and illiteracy was taken into account.

Although the rate of literacy in the northern Netherlands, with its dense network of schools both in towns and in the countryside, was high compared to other European countries at the time, part of the population could neither read nor write or was semi-literate. As reading and writing were taught in succession, not simultaneously, those who were able to read may not have had any writing skills (Blaak 2009: 3-4; Kuijpers 1997: 501). The ability to sign a name on a document has been considered an appropriate and direct measure of literacy (Houston 2013: 132-134). On the basis of such measures in signature studies of marriage registers, it is commonly estimated that two-thirds of the male population and one-third of the female population in the northern Netherlands in the second half of the seventeenth century were 'literate'; for social stratification, the literacy estimates are one-third of the lower ranks and two-thirds of the higher ranks of society (Frijhoff and Spies 1999: 237-238). ${ }^{3}$ Thus gender and social class differences were revealed. At the same time, we have to realise that this signature literacy may cover a considerable diversity in reading and writing skills, ranging from almost semi-literacy to full literacy. Moreover, these literates may not all have used their reading and writing skills regularly and thus differed in reading and writing experience. Writing a signature differs from writing a letter to communicate with loved ones at a distance. For writing a letter, illiterates, semi-literates and those with insufficient writing experience had to rely on more experienced writers, professional scribes or social writers. ${ }^{4}$ The senders or recipients of letters in some cases explicitly mention these circumstances: they regret their illiteracy or semi-literacy which prevents them from revealing their feelings and implies a lack of privacy (cf. van der Wal 2014). An illustrative example is Claas Jansen's letter from Guadeloupe, written on 10 December 1664 and addressed to his wife Susanneke in the town of Middelburg (province of Zeeland). He urgently requests her to send letters even if she has to pay a writing fee and regrets that his wife's lack of writing experience means that een ander weten moet hoe dat het met ons is 'someone else has to know how things are between us'. ${ }^{5}$ In such few cases the letters themselves inform us about the reading or writing skills of the senders and recipients and the possible assistance of delegated readers and writers. In most cases, however, we had to establish whether or not the letters were written by the

3 Gender differences were still found in the nineteenth and early twentieth centuries. See Lyons (2014: 252-253) for France, Spain and Italy.

4 In this article, I use the terms scribe and writer as synonyms for stylistic reasons. See also footnote 1 .

5 Claas Jansen's letter is part of my additional collection of letters, BAB2/LAL2, recently published at http://brievenalsbuit2.ivdnt.org. 
senders themselves and whether or not they were autographs and as such represented the language use of the senders. In order to deal with this problem, we developed the so-called Leiden Identification Procedure (LIP), which combines script and content analysis with research of archive material such as marriage registers, last wills and notaries' documents. For details of this procedure I refer to Nobels and van der Wal (2012) and Nobels (2013: 53-76). The ultimate result was a division of the seventeenth-century part of the $L A L$ corpus into autographs, nonautographs and, in cases where we had insufficient proof, into letters with an 'unclear status'. ${ }^{6}$ This result allows us to concentrate on established seventeenthcentury non-autographs for our exploration of delegated writing and to compare them with established autographs.

\section{Quantitative research: formulae in autographs versus non-autographs}

In the Early and Late Modern Dutch private letters, we find a large variety of what appear to be epistolary formulae, which can be distinguished into four main types: text type, intersubjective, Christian-ritual and text-structural formulae (cf. Elspaß 2005: 157-196; Rutten and van der Wal 2014: 75-172; Wray 2002). ${ }^{7}$ A letter is first of all characterised by text type formulae such as an address, opening, closing and signature. An illustrative example is the Looft God in [een bepaalde plaats], op [een bepaalde datum] 'Praise God in [a particular place], at [a particular date]' opening formula, which, with its variants Looft God boven al 'Praise God above all', Looft God 'praise God' or Looft God waar dat gij sijt 'Praise God wherever you are', is frequently found in seventeenth-century letters. ${ }^{8}$ Other frequent formulae are the intersubjective formulae which focus on the relationship between the writer and the addressee. Among these we find the four-partite or even more extended health formula Ik laat $u$ weten dat ik kloek en gezond ben 'I let you know that I am in good health'/Ik hoop dat het met u ookzo is 'I hope that the same applies to you'/Ware het anders het zou mij van harte leed zijn om te horen 'If it were different, I would be very sorry to hear that'/Dat weet God die een kenner is van alle harten 'As God knows, who is an expert of all hearts'. The most frequent Christian-ritual formula is the

6 The eighteenth-century part of the $L A L$ corpus consists of only autographs (cf. Rutten and van der Wal 2014: 13-17). In previous publications I used the term encoder for a delegated writer.

7 Examining Early and Late Modern letters, we notice changing fashions: some formulae characterise seventeenth-century letters and become obsolete in the eighteenth century (cf. van der Wal and Rutten 2013b: 24-27; van der Wal et al. 2018).

8 The formula occurs in 259 of 545 seventeenth-century private letters in the $L A L$ corpus (48\%). 
commendation formula with which the writer commends the addressee into the hands of God: Sijt God bevolen 'be commended to God' and its variants. Yet another function, i.e. marking the transition from one part of the discourse to another, is fulfilled by the so-called text-structural formulae, such as Ik laat $u$ weten dat 'I let you know that' which initiates discourse or indicates a change of topic. These textstructural formulae are very convenient strategies in letters which frequently lack punctuation and paragraphs. Similar formulae of all four types are found in private letters from other European language areas (cf. Austin 1973: 16, 2004; Elspaß 2005: 165, 168-170; Laitinen and Nordlund 2012: 69-70), which points clearly to a shared epistolary tradition in Western Europe (cf. among others Nevalainen 2001; Poster and Mitchell 2007).

In previous research we examined the formulaic writing in seventeenthcentury autographs versus that in non-autographs, focusing on six frequent formulae: the intersubjective opening formula een vriendelijke groetenisse zij geschreven aan 'a friendly greeting be written to', three different parts of the health formula (kloek en gezond 'strong and healthy', het zou mij van harte leed zijn om te horen 'I would be very sorry to hear that', and the Christian ritual part dat weet God die een kenner is van alle harten 'God who is an expert of all the hearts knows that') and the two text-structural formulae $i k$ laat $u$ weten dat 'I let you know that' and voorts 'furthermore'. Figure 1 shows the frequency per 10,000 words in the subcorpus of autographs (219 autographs, 102,000 words) versus the subcorpus of non-autographs (116 non-autographs; 45,000 words).

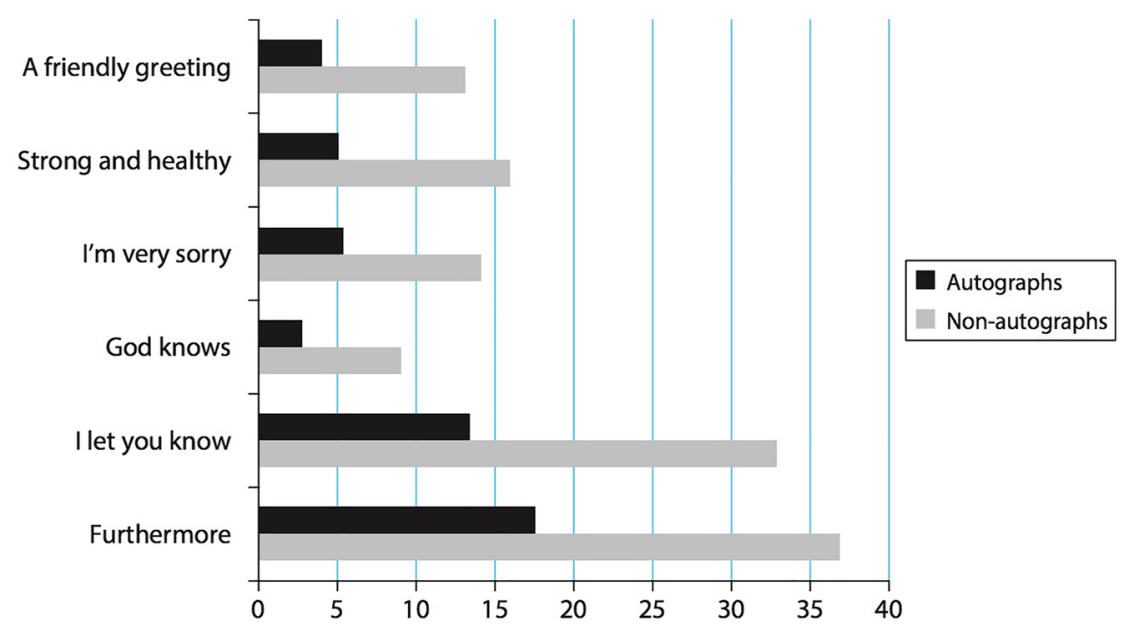

Figure 1: Frequency of six formulae in the seventeenth-century autograph and non-autograph subcorpora (Rutten and van der Wal 2014: 179). 
Clearly, in the non-autographs, the frequency per 10,000 words approximately tripled in the case of the first four formulae and (more than) doubled in the case of the last two formulae. Thus the letters in the non-autograph subcorpus appear to be more formulaic than the letters in the autograph subcorpus. Linking this to the writing process, this quantitative linguistic evidence reveals an important characteristic of delegated writing: the fixed formatting of formulaic language must have been convenient to social and professional writers or, in other words, it must have been common practice for them to rely on formulaic language. ${ }^{9}$ Apart from this specific characteristic, our quantitative research does not inform us in more detail about the roles of scribe and sender. We will now examine whether qualitative research may allow us to discover more about the actual process of delegated writing.

\section{Qualitative research: zooming in on particular cases}

In Section 1, I briefly mentioned different scenarios for the roles of scribes and senders. Did the scribe complete a particular format, did the sender of a letter dictate the contents or did they collaborate in some way? Most cases of nonautographs do not allow us to make plausible assumptions, but zooming in on a few specific cases may shed light on the respective roles of scribe and sender.

In the cases of delegated writing either a professional or a social writer is involved. In particular letters, the neat handwriting and lay-out point in the direction of a professional scribe. An illustrative example is three letters, dated 8 November 1672 and sent by different lower-class and lower-middle class women in the town of Enkhuizen to two husbands and a brother in Batavia. ${ }^{10}$ A comparison of the contents of the letters also shows almost identical formulae, such as the opening and health formulae at the beginning of the letters, which has to be attributed to the unknown, professional writer. Often we do not know who the professional or social writers were, but in some cases we did discover their identity. For instance, Geertruyt Weckmans, living in New Netherlands, sent two letters to her former mistress Geertruyt Boetselaer in the Netherlands in $1664 .{ }^{11}$ For these letters in different handwritings, signed with her name in yet another (her own)

9 See Rutten and van der Wal (2014: 132-172) for the function of fixed formulae as formulating help for less experienced writers of autographs.

10 See the $L A L$ Corpus for these letters sent by Meintje Doedes, Cornelisje Jacobs, both lower class, and Antje Christiaans, lower-middle class.

11 These letters are part of one of my additional collections of letters, not available online. 
handwriting, she appears to have relied on the help of successively a professional and a social writer, who were identified as the secretary and part-time schoolmaster Ludovicus Cobes/Cobus (her first letter), and her husband Pieter Meessen Vroman (her second letter) (for further details see van der Wal and Rutten 2013a). In these and other cases, less experienced writers or illiterates looked for assistance in their immediate environment, that is in their town or region or among the crew aboard ships. A familiar social writer probably was the most attractive and cheapest option. Even aboard ships, members of the crew are assumed to have relied on friends and colleagues rather than on the professional ship's writer who wrote administrative documents and letters for the captain (see van Alphen 2014: 161-164).

Exploring and examining the whole seventeenth-century subcorpus of letters, we were able to establish the identity of the letter writers in about a quarter (27) of the 116 non-autographs, referred to in Section 3. I cannot go into the details of this identification process here, but only mention the result: in the case of these 27 letters, 17 different letter writers appeared to be involved, as various letters were written by the same delegated writer. Six of these writers were only indicated by a name or a relationship such as son Antheunis Verbrugge and nephew Jan Roelandsz Adolphus, who wrote letters for Maaike/Maiken Andries in the town of Flushing. For Sijtje Minnes in Amsterdam, it was her son-in-law, for Dorothee Pieters in Amsterdam her brother Willem Pieters, for Fijtje Krijnse in Rotterdam her son Cornelis Gerritse Slingeland and for Tanneke Boudewijns in Rotterdam her mother Anneke Jacobs who were all social writers of whom only the delegated letters survived. In the case of the other eleven identified delegated writers, three male and eight female, we found not only the delegated letters, but, amazingly, also one or more non-delegated letters by the same scribe. We were thus fortunate to possess two types of letters, both delegated and autograph, which offered opportunities for our linguistic approach. Comparing autograph and delegated writing may reveal similarities and differences which could shed light on the process of delegated writing. Moreover, our archival research of local registers of marriage, baptism or burial and registers of contemporary notaries provided us in quite a few cases with personal information (metadata) on the senders and writers of the letters which enabled us to gain a more detailed picture of the agents involved in this process.

The three male writers all sent their letters from various destinations abroad; apart from one female writer, all others sent their letters either from the town of Rotterdam or Amsterdam. The only female writer from abroad was Elisabeth Emerij, who wrote a letter from Surinam to Helena Backx's brother in the town of 
Middelburg. ${ }^{12}$ My preliminary research showed that, for revealing the process of delegated writing, the female letter writers were the most interesting to examine in detail. In the case of the male writers, either the scenario appeared to be obvious or metadata on the senders and scribes were scarce. An illustrative example is the case of Karel/Charles Belleman, who was probably a captain of a European trade ship. On 8 December 1664, he wrote, apart from a letter to his wife, also three almost identical letters for three fellow seamen, addressed to their wives in Oostende. These letters point immediately to the scenario of a scribe completing a particular format; furthermore, metadata on the senders and the scribe are lacking. In the case of the female writers, the scenarios seemed, at first sight, more diverse and metadata could be found which clarify the relationships of senders and delegated writers. Moreover, it is fascinating to discover that, despite their generally lower literacy rate, women appeared to serve as delegated writers for others. I will therefore concentrate on the diverse cases of female delegated writers in the following Sections 5 and 6. In practice, I will examine in detail six of the eight female delegated writers, as Elisabeth Emerij's letters mentioned above appeared less suitable for comparing and Marretje Philipse's letters are part of a larger, more complex collection of family letters which need separate attention. ${ }^{13}$

\section{Cases of female delegated writers}

\subsection{A captain's wife accumulating formulae}

Kathelijne Haexwant (ca. 1615-1676), wife of Captain and Rear Admiral Leendert Ariensen Haexwant (1599-1678), wrote long, elaborate letters to her husband, varying from circa 800 to circa 1,900 words each. Apart from telling him about the arrangements she made, she was also sending greetings from wives of the crew on the three ships from Rotterdam which were part of Admiral Michiel de Ruyter's fleet in 1664. On 31 October 1664, Kathelijne Haexwant appears to have been a delegated writer for at least one of these wives, Joosje Cornelis (Figure 2). The relatively brief letter, sent by Joosje to her husband Jonas Pietersz., first mate on the ship Princes Louise, consists of

12 Elisabeth Emerij, her husband, merchant Nicolaas de Zoutte, and Helena Backx all originated from the province of Zeeland. It is not clear what the relationship was between Helena Backx and Elisabeth Emerij and her husband.

13 Apart from one autograph, Marretje Philipse wrote five letters as delegated writer for her sister Elisabeth Philipse Ameling to Elisabeth's husband Lukas Pruijs. Elisabeth also wrote letters herself and one letter may have been written for her by a professional scribe. An issue for further research is whether in this case Marretje's delegated writing may actually be copying for so-called eveleens sending, the sending of identical letters at the same time via different routes. 
accumulated formulae with only a very brief non-formulaic interlude, marked below in bold. ${ }^{14}$ After the address formula, the letter runs as follows ${ }^{15}$

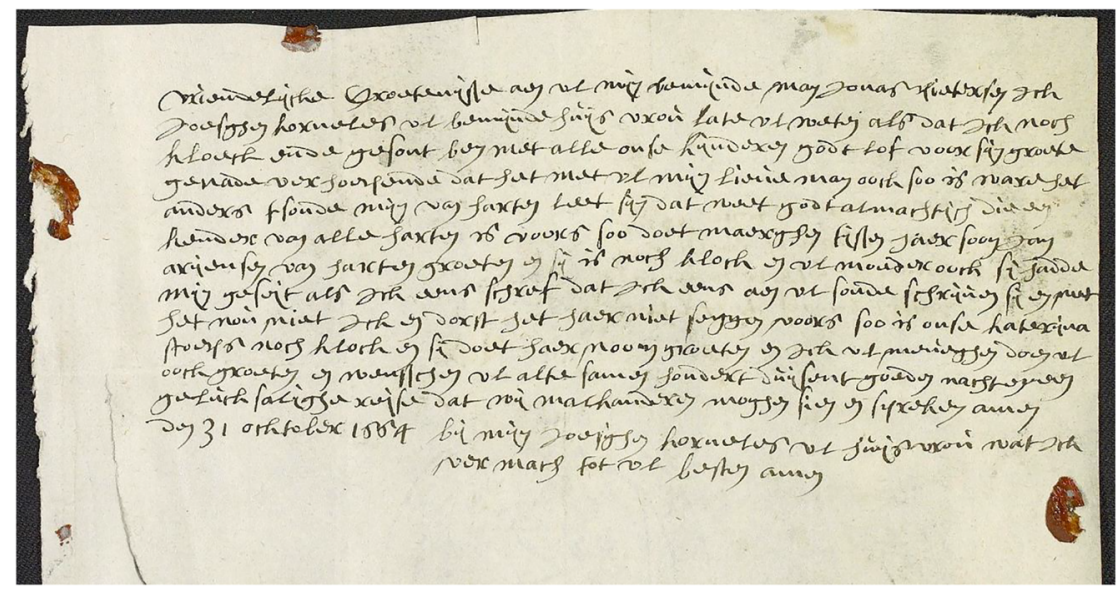

Figure 2: Delegated letter written by Kathelijne Haexwant for Joosje Cornelis.

(1a) 'A friendly greeting to you, my beloved husband Jonas Pietersen. I, Joesghen Korneles, your beloved wife, let you know that I am still strong and healthy with all our children. Praise God for his great mercy. I hope that you, my dear husband, are also like that. If it were different, I would very much regret to have to hear that. That knows God almighty, who knows all the hearts. Furthermore, Maerghen Tyssen sends hearty greetings to her son Jan Arijensen. And she is still healthy, and your mother too. She had told me, that if I would write again, that I would write to you. She does not know it now. I did not dare to tell her. Furthermore, our Katerijna Stoeps ${ }^{16}$ is still healthy, and she sends her uncle her greetings, and I, your aunt, send you also my greetings, and I wish you all together a hundred thousand good nights and a blessed journey. That we may see and speak to each other. Amen. 31 October 1664. By me, Joesghen Korneles, your wife. Whatever I am capable of to do in your interest. Amen.'

14 See for this letter the $L A L$ corpus and van Vliet (2007: 288-289).

15 See Rutten and van der Wal (2014: 180-182) for a discussion of the same letter in the context of gender- and class-crossing in delegated writing.

16 Katerijna Stoeps/Katharina Stoops was a daughter of Joosje’s brother Claas Cornelisz. Stoop and Adriana Dirks Verburch. 

Dutch original
vriendelijcke groetenijsse aen ul mijn bemijnde man jonas pietersen jck joesghen korneles ul bemijnde huijsvrou late ul weten als dat jck noch kloeck ende gesont ben met alle onse kijnderen godt lof voor sijn groete genade verhoepende dat het met ul mijn lieue man oock soo is ware het anders 't soude mijn van harten leet sijn dat weet godt almachtijch die een kender van alle harten is voors soo doet maerghen tyssen haer soon jan arijensen van harten groeten en sij is noch klock en ul moeder oock sij hadde mijn geseijt als jck eens schref dat jck eens aen ul soude schrijuen sij en weet het nou niet jck en dorst het haer niet seggen voors soo is onse katerijna stoeps noch klock en sij doet haer noom groeten en jck ul meueghen doen ul oock groeten en wensschen $\mathrm{ul}$ altesamen hondertduijsent goeden nacht en een gelucksalijghe reijse dat wij malkanderen moghen sien en spreken amen den 31 ocktober 1664 bij mijn joesghen korneles ul huijsvrou wat jck vermach tot ul besten amen

The letter opens with the familiar seventeenth-century greeting formula $A$ friendly greeting [be written] to you, my beloved husband Jonas Pietersen, immediately followed by the elaborate health formula including a Christian-ritual part. The text-structural formula furthermore marks the transition to another set of greetings and health statements and a very brief non-formulaic interlude (bold part). This non-formulaic message is followed by another furthermore, again introducing greetings and health formulae. The letter ends with the wishes of a hundred thousand good nights, a blessed journey, and the contact formula That we may see and speak to each other. The date and the name of the sender (not the writer) at the very end are interwoven with closing formulae such as amen and whatever I am capable of to do in your interest.

Kathelijne Haexwant was identified as the writer of Joosje's letter on the basis of her handwriting, but by the end of the letter she also manifests herself as delegated writer when greeting the addressee with the phrase $I$, your aunt, send you also my greetings. ${ }^{17}$ Here the letter deviates from the chosen perspective of sender Joosje. From our previous quantitative research, we know that delegated letters are rather formulaic (see Section 3). Remarkably, the letter for Joosje is not only merely highly formulaic, but the formulae are also completely similar to those used by

17 Kathelijne also mentions Joosje as her niece (onse joesghen nicht) in her letter dated 16 November 1664. According to archival information, the actual 'aunt - niece' relationship was based on the marriage of Joosje's brother Claes Cornelisz. Stoop and Adriaantje Verburch, Kathelijne's daughter from her first marriage with Captain Dirck Gerritsz. Verburch. 
Kathelijne Haexwant in her own letters. ${ }^{18}$ In sum, Kathelijne's practice as delegated writer can be characterised as accumulating her own familiar formulae with integrating only a single individual interlude which has to be attributed to Joosje herself and could possibly be a quote.

\subsection{Susanna Jans writing for her mother-in-law}

Susanna Jans' husband, Lodewijk Jacobsen, was a member of Captain Haexwant's crew on the ship the Rotterdam. Two of Susanna's letters, dated 20 September and 25 November 1664 and sent to her husband, survived. The four-sided sheet of paper on which her letter of 25 November 1664 was written, also contains a letter in identical handwriting from Lodewijk Jacobsen's mother. ${ }^{19}$ Susanna obviously functioned as delegated writer for her mother-in-law, whose name, Jannetje Lodewijck, is lacking.

A comparison of the three letters shows that the formulaic first part of the delegated letter consists of greeting, health and Christian-ritual formulae identical to those in Susanna Jans' other two letters. Self-evidently, only the slots for the addressee differ: my beloved husband versus my beloved son. The familiar structural formulae furthermore, I let you know introduce the non-formulaic middle part, the contents of which differ more or less. In Susanna's letter dated 20 September, she mentions financial matters, the sending and reception of letters, again a health statement and news about the passing away of a relative. The middle part of her letter dated 25 November comprises remarks on the exchange of letters, the destination of the fleet and her wish for a safe return of her husband. The letter sent by his mother and fully written from her perspective informs Lodewijk Jacobsen of his eldest daughter's ill health, which, his mother stressed, had meant a lot of trouble for his wife.

Susanna's September letter ends with nothing more as be recommended to the Lord and the familiar seventeenth-century wishing of a hundred good nights, and a safe journey:

(2) en mijn moeder wenst $U L$ hondert goede nacht en gelock en behouden reeys en al de kinders en fop iansen wenst $U L$ hondert goede nacht ' and my mother wishes you a hundred good nights and good fortune and a safe journey and all the children and Fop Jansen wish you a hundred good nights'

18 One of Kathelijne's letters is part of the online $L A L$ corpus; four others are part of my additional collection of letters, BAB2/LAL2, recently published at http://brievenalsbuit2.ivdnt.org. See also van Vliet (2007: 52-53, 295, 314-333).

19 These letters are part of the online $L A L$ corpus. See also van Vliet (2007: 347-349, 352-353). 
The good night wish is also present in the delegated letter in the hundred thousand variant, which we also found in Kathelijne Haexwant's letters (Section 5.1). ${ }^{20}$ The very popular seventeenth-century good night formula, which as in (2) often occurs more than once in a letter, varies mainly in the numeral slot, filled with huge numbers such as veel 'many', (veel) duizend 'thousand(s)', (veel) honderdduizend 'hundred thousand(s)' (the addition of veel indicates a plural). The word nights originates in the convention of using the night to indicate a time period, such as in English fortnight, Dutch veertiennacht for a period of fourteen days. ${ }^{21}$ Furthermore, the delegated letter ends with similar phrases to those in Susanna's November letter: bit godt dat hij $v$ l weeder met gesonheijt weeder te lande wilt brengen 'pray to God that he will bring you again in health again to the land/ home' and niet meer als blijft den heere beuoolen 'nothing more/else as be recommended to the Lord'.

In sum, Susanna Jans' delegated letter is written from the perspective of her mother-in-law, just as Kathelijne Haexwant's letter was written from Joosje Cornelis' perspective. The phrasing of the delegated letter appears to be similar to Susanna's two autographs: similar greetings, health and Christian-ritual formulae in the first part of the letter and similar good night wishes, safe journey wishes and commendation formulae in the closing part. Both Kathelijne Haexwant and Susanna Jans wrote relatively brief delegated letters of almost 200 words. Our next case of a lengthier letter of circa 500 words allows us to make a more detailed comparison of structure and phrasing.

\subsection{Josje Elias Verburg determines structure and phrasing}

On 20 September 1664, Josje Elias Verburg wrote a letter to her husband Thomas Lambertsen, boatswain's mate on Captain Haexwant's ship the Rotterdam. On the same date she served as delegated writer for Grietje Martens/Maertens, whose husband Jacob Bartelemesse, a gunner's mate, was also a member of the crew of the Rotterdam. ${ }^{22}$ Comparing these letters, which both contain 500 to 550 words, we will notice a similar structure and phrasing.

20 For this popular wish see van der Wal (2016: 211-213) and van der Wal et al. (2018: 455-457). 21 More marginal occurrences are (veel) tienduizend 'ten thousand(s)', (veel) honderd 'hundred(s)', veel duizend maal duizend 'thousands times thousand', veel honderduizend maal duizend 'hundred thousands times thousand', miljoen 'a million' and (veel) honderdduizend maal 'hundred thousand(s) times'. For the meaning of night see the lemma NACHT in the online historical dictionaries MNW and WNT at gtb.inl.nl.

22 Another, incomplete letter, dated 15 November 1664, also survived. The three letters are part of the online $L A L$ corpus. See also van Vliet (2007: 302-303, 310-313). 
To begin with, the address formula of the delegated letter and Josje's own letter is almost identical: To the honourable discrete [name], sailing on the ship Rotterdam, by Captain Haexwant with the addition of the formula With a friend who God may save over sea, a frequent formula which mentions the bearer of the letter. ${ }^{23}$ The structure of the letters is similar: starting with the familiar Praise God above all and the A friendly greeting be written to formulae, followed by the text-structural formula I let you know that, which introduces the elaborate health formula (see Section 3). After that similar formulaic part the switch towards real news is made by the text-structural phrase furthermore, I let you (...) know that. In Josje's letter, this formula introduces an elaborate report on her pregnancy and the birth of a son (166 words against 91 words of the formulaic introduction), followed by yet another switch, introduced by a similar phrase, a switch towards a message about the marriage and pregnancy of her husband's sister. In the delegated letter, the furthermore, I let you know phrase firstly introduces news about relatives' illnesses and the contemporary serious plague (65 words against 78 words of the formulaic introduction) and, when repeated, introduces the request to bring white cloth. Striking similarities also appear in the two contact formulae, the wish to meet each other either on this earth or later in heaven: [I hope] that God the Lord will make us meet again (1) and if it does not please Him, that we will meet in eternity (2). The final phrases of the letters are also very similar with only the variation healthy (Dutch variants gesont and klock): nothing more for now than mother and brothers and sisters and all relatives are still healthy and they all together greet you. In the postscriptum of the delegated letter Josje greets her husband, but, unlike Kathelijne Haexwant's greeting, she maintains the perspective of sender Grietje Martens: and do so much and say good night to Thomas Lambertsen on behalf of his wife. The phrasing of this postscriptum is more or less similar to that in Josje's own letter in which she sends her greeting to a crew member.

In sum, Josje's delegated letter of considerable length (ca. 500 words) comprises both non-formulaic content and rather formulaic parts. The structure of the letter and the formulaic parts are strikingly similar to Josje's own letter. The different private content, such as the request for white cloth, more letters and a remark on the expected prize fee, may be attributed to Grietje Martens. We conclude that Josje Elias Verburg determined the structure and the phrasing of the elaborate delegated letter, while maintaining the perspective of sender Grietje

23 Dutch text: Aen den eersamen discreten Jacob Bartelemesse, constapelsmaet, varende op het schip Rotterdam, bi cappetein Haexwant. Met vrient die Godt bewaert over see. The formula Met vrient die Godt bewaert over see is also found in the November letter of which only the first part survived. 
Martens in the whole letter. In the next case we will come across a striking characteristic: letter writer Elsje Wijbrants appears to be fond of religious phrasing.

\subsection{Fond of religious phrasing}

On 11 November 1664, Elsje Wijbrants, living at Prinsengracht in the town of Amsterdam, wrote not only to her husband, Lieutenant Jan Willemsz., but also at the request of Maartje Reijnders to Maartje's husband Cornelis Sijmensz., a gunner's mate. ${ }^{24}$ Jan Willemsz. and Cornelis Sijmensz., both of foreign origin (according to the marriage register, from Flensburg and Christiaanshaven respectively), belonged to the crew of De Spiegel, the ship commanded by Admiral De Ruyter. Maartje Reijnders, who originated from Emden, and Elsje Wijbrants knew each other well: Elsje had been a witness at Maartje's marriage on 20 March 1660. Maartje was illiterate or semi-literate: she signed her marriage record with a mark. $^{25}$

The two letters differ considerably in length (518 vs. 247 words), but show remarkable similarities in formulae and religious phrasings. The address and the opening formulae are similar, but the phrase with a friend who God may save is missing from Elsje's address, whereas her opening formula is more elaborate. In contrast to simply Praise God above all in Amsterdam 11 November in the delegated letter, in her own letter Elsje uses the extended formula Praise God wherever you are in the year 166411 November elaborated with the biblical quote if God is with us, who can [be] against us (Epistle to the Romans 8: 31). Biblical quotes and religious phrasings appear to characterise Elsje's writing. In both letters the health formula follows, partly similar, partly different. After elaborate information on the illnesses and deaths of relatives and friends, Elsje switches with a religious phrasing to information about victims of the plague

(3) 'the great father in heaven, the king of kings, be praised and thanked for his mercy that the dying diminishes, the good God does not strike without healing again, now 3 to 400 deceased a day that is true but it has been even 900. 26

24 According to the marriage records, Elsje lived at Prinsengracht. The letters are part of the $L A L$ corpus. See also van Vliet (2007: 90-91, 132-133).

25 See the Amsterdam City Archive online: https://archief.amsterdam/indexen/persons.

26 The Dutch text is the following: dije grote vader sijnde hogen hemmel ija konck daer kongen sij lof en danck voor sijn genade dat het sterven afnemt de goede godt slaet niet of heij salft weer nv ist 3 a 400 en dach wech dat is waer maer het wel 900 gevest. 
The same information about the number of casualties is found in the closing part of the delegated letter, but without the religious phrasing.

The remark on the reception of a previous letter (more detailed, mentioning the ultimate destination Guinea in the delegated writing) is followed in both cases by the wish that the husbands will arrive safely home under the protection of the Lord and his holy angels: I hope that the Lord will lead you with [the convoy of] his holy angels. In Elsje's letter this similar phrasing is extended by the biblical reference during the day in a column of clouds and in the night in a column of fire, referring to the way in which God led the people of Israel through the desert (Exodus 13: 21-22). ${ }^{27}$ Furthermore, we find alternative religious phrasings in the two letters. In Elsje's letter: we have to expect the blessing from the good God, he can give where nothing is. The delegated letter varies three times on the topic of protection (the good God will protect you all together/who are in Gods protection have no sorrow/whom God protects he is well) and twice on what the Lord may give ([that the Lord will] give that we will meet again in health. That may God give us as bliss amen).

Elsje's longer letter also includes national news items such as the death of the Frisian Count Willem Frederik following an accident with his pistol cleaning. The health of Maartje and her children is mentioned in a postscriptum, followed by quite a few lines on the health of other people who apparently came to Elsje's mind. The perspective of sender Maartje is maintained in the delegated letter with the message cousin Elsje is still healthy. The closing of both letters occurs with slightly different closing formulae. The formula nothing more at this time than in the protection of the most highest is extended in Maartje's letter with the interwoven formula thousand good nights and days and God in mercy recommended. Both letters close with the formula whatever I am capable of to do.

In sum, the letters differ in length and content, but show remarkably similar religious phrases, which have to be attributed to Elsje Wijbrants who makes extensive use of biblical quotes and religious phrases in her autograph. A few alternative religious phrasings in the delegated letter are also assumed to be the work of Elsje, who obviously selects from her stock of religious phrases.

The female delegated writers we have discussed so far wrote a letter for one particular friend or relative. In two other cases, the delegated writers performed their tasks twice for different individuals: Jaapje Koerten (Section 5.5) and Trijntje Cornelis (Section 6).

27 In just a few other letters of the $L A L$ corpus, we find similar phrasings. The protection by the convoy of angels occurs in Wolf Schoneveld's letter to his friend Cornelis Walraven (1664). The columns of clouds and fire are found in Belijtje Jans' non-autograph to her husband Jan Jansen (1664), Aaltje Hendriks' non-autograph to her husband Thomas Jansz. Weiland (1671) and Hieronymus Sweerts' letter to his friend Martinus Bruno (1672). 


\subsection{Jaapje Koerten functioning twice as delegated writer}

When Jaapje Koerten wrote to her friend Jan Karstensz., a common sailor, on 19 November 1664, she had previously functioned twice as delegated writer. On 10 October 1664, she had written a letter for Grietje Martens to her friend Cornelis Mangelaar, a common sailor from Zeeland, and on 27 October 1664, one for Lijsbet Jelis to her husband Albert Jansz., master carpenter. ${ }^{28}$ The addressees belonged to the crew of De Spiegel, the ship commanded by Admiral De Ruyter, and the senders all lived in the town of Amsterdam. With hardly any additional data such as names of a husband or children in the letter itself, the identity of sender Grietje Martens is difficult to establish on the basis only of her frequent, common name. ${ }^{29}$ The marriage record of Lijsbet Jelis/Jillis and Albert Jansz./Janse, dated 22 September 1661, reveals that neither was able to write and thus needed a delegated writer (Figure 3).

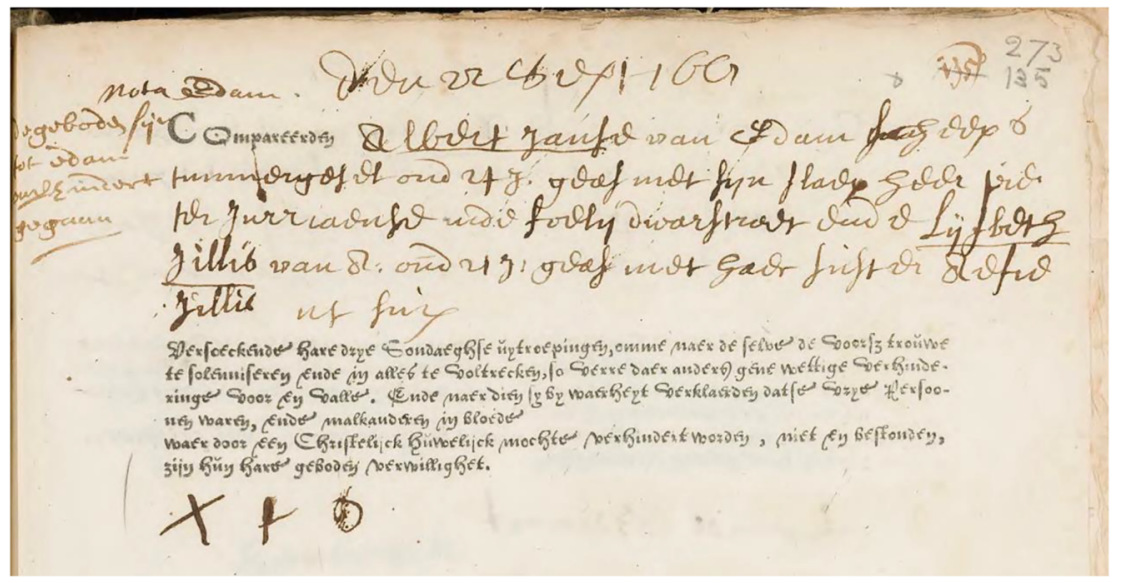

Figure 3: Marriage record of Lijsbet Jillis and Albert Janse with their marks instead of signatures (Amsterdam City Archive).

28 The three letters are part of the $L A L$ corpus; see also van Vliet (2007: 102-105, 112-115, 126-127). Jaapje Koerten's signature is found on her later marriage record, dated 05.12.1665. She married at the age of 21 and the groom was not her friend Jan Karstens, but Andries Zijbrants, aged 25, who was not able to write.

29 Examining the many individuals named Grietje Martens/Maertens/Meertens in Amsterdam in the period 1650-1665, a probable identification could be Grietje Meertens who married Cornelis Ariaensz. on 18 February 1651. According to the marriage records, Grietje Meertens was not able to write. They had five children of whom one obviously died before 1658: Marten baptised 13.07.1653; Arian 25.04.1655; Marritje 08.10.1656; Arian 13.01.1658; Cornelis 06.02.1659. A problem, however, is that the online available burial data do not mention the death of her husband and two children in the year of the plague (1664), at any time before the letter of 09.10.1664. 
After the opening formula a friendly greeting, the three letters immediately start with the text-structural I let you know that formula, followed by private news about the health of the senders and their families. Lijsbet Jelis explicitly mentions that she and her new-born daughter are healthy, whereas one of her sisters lost her only daughter and another sister her youngest child. ${ }^{30}$ Jaapje Koerten suffered from the plague, but is recovering. Grietje Martens, however, lost her husband and her two youngest children; she herself and her two eldest children were also very ill, but recovered. The saddest part for addressee Cornelis Mangelaar was yet to come, introduced by furthermore, I let you know that: his wife died six weeks previously. ${ }^{31}$ After this brief and sad message, Grietje immediately continues with and you know well that, introducing an elaborate explanation of her financial problems and uttering a cry for help.

Jaapje Koerten, who also elaborates on the departure of Jan Karsten's father to Norway, uses the furthermore, I let you know that formulae three times to structure her letter into paragraphs and Lijsbet Jelis' letter also comprises three instances of that same text-structural phrasing. The closing of the three letters also shows remarkable similarities. After now nothing more at this time than follow the familiar good night formula I wish you my very beloved and good friend hundred thousands good nights and an extensive commendation formula interwoven with the wish to see each other again. The guidance of God with his holy angel is integrated in the commendation formula: with this recommended to the almighty God who will lead you with his holy angel that we may see each other again in good health to our salvation amen. The signature by me Jaapje Koerten your friend includes the formula whatever I am able to do. ${ }^{32}$ The very same phrases are to be found in the two other letters, although whatever I am able to do is missing from Lijsbet's letter. This letter, however, contains an elaborate religious phrase with biblical references to the Proverbs (1: 7, 9: 10)

30 Lijsbet's daughter Niesje was baptised on 1 August 1664 (the Amsterdam City Archive online: https://archief.amsterdam/indexen/persons).

31 Cornelis Adriaense Mangelaer, originating from Zierikzee, profession sailor, married Mayetje Maertens on 6 May 1656 in the town of Flushing. When he became a member of the Reformed Church on 27 March 1657, the name of his partner was registered as Matien Maertens and his address as Lange Noortstraete, Flushing.

32 The Dutch text: nu geen meer op dit pas dan ick wensche v l mijn seer lieve en goede vrient veel 100 duijsent goede nacht and hier meede den al machtijgen godt bevoolen die $v 1$ met sijnen heijlijgen engel wil gelaijden dat wij malkanderen met lief weeder sien moogen tot onser salijcheijt amen bij mijn iaepien koerten $v$ l vriendinne wat ick vermach. 
(4) 'beloved husband, keep always God in mind and do not let you seduce by bad company as Salomon learns us, but fear God the Lord always in your heart, for the fear of God is the beginning of wisdom as Salomon says. ${ }^{33}$

Due to external circumstances, the contents of the three letters differ considerably, but similar formulae and religious phrasings occur in Jaapje Koerten's autograph and her two delegated letters. The formulae do not differ from our previous cases of female delegated writing, the religious phrasings remind us of Elsje Wijbrants' practice and the usage of the Ilet you know that formula structures the text just as in Josje Elias Verburg's letters.

Having examined five cases, we may conclude so far that the delegated writers were part of the social network of the senders: they had a family relationship or knew each other as wives of the fleet crew. These delegated writers in most cases maintained the sender's perspective and appear to determine the structure and phrasing of the delegated letters, which show strong similarities with the social writer's own letters. Instances of clearly marked literal quotes were not found, although parts of the content may be attributed to the sender. The sender, however, is almost invisible in these cases. This differs in yet another interesting case, that of social writer Trijntje Cornelis.

\section{Trijntje Cornelis writes for both an illiterate and a literate friend}

\subsection{Two different cases}

On 25 May 1672, Trijntje Cornelis, living in Amsterdam, wrote a letter to her husband skipper Abraham Schepmoes and on the same date another one as delegated writer to Mette Jans' husband, skipper Ernst Ronge. Two days later, Trijntje functioned again as delegated writer, this time to write to Neeltje Jacobs' husband, Juriaan Leendertsen, first mate on Schepmoes' ship. ${ }^{34}$ There were different reasons for assisting these two women. Mette Jans was an illiterate or partly literate woman, who may have been able to read, but could not even write her own

33 The Dutch text: lieve man hout doch altijt godt voor oogen en laet $u$ daer doch niet van het quaet geselschap verlaijden soo salemon ons dat leert maer vreest godt den heere altijt in $u$ harte want de vreese des heeren is het beginsel der wijsheijt soo salemon seijt.

34 The three addressees were sailing on ships in the Caribbean (Curacao). According to Brouwer (2014: 107), the three women all lived in the same street, the Haarlemmerdijk in Amsterdam. 
signature on the marriage record. ${ }^{35}$ Neeltje Jacobs, however, was temporarily not able to write due to childbirth. She signed her marriage record and one of her autograph letters, dated 25 May 1672, survived. Therefore, in this case we have a visible sender and two opportunities for comparison: the two delegated letters can be compared not only with Trijntje Cornelis' own letter, but also with Neeltje Jacobs' autograph. ${ }^{36}$

\subsection{Writing for an illiterate friend}

Trijntje's own letter and the delegated letter for Mette Jans are both almost 300 words long. After a similar address formula, the Latinised variant of the Praise God formula follows in both letters: Laus deo In Amsterdam den 25 maijus anno 1672, a formula which is less frequent in our seventeenth-century $L A L$ corpus than the Dutch variant. ${ }^{37}$ Trijntje's own letter simply continues with my beloved husband, whereas the familiar formula $A$ friendly greeting be written to my beloved husband occurs in the delegated letter. After the health formula, which is somewhat more elaborate in Trijntje's own letter, the phrase furthermore is my writing not much special than that introduces the non-formulaic news in both letters. Trijntje's news, however, is more shocking than Mette's remark on her husband's location and health, about which she was informed by sailors returning from the Caribbean. Son Jan passed away on Sunday 22 May and will be buried on Thursday 26 May, which causes Trijntje great sadness. The Amsterdam City Archive reveals the details of this sad news: Jan, son of Abraham Janse Schepmoes and Trijntje Cornelis, was baptised on 18 February 1672 and buried on 26 May in the cemetery of the Noorderkerk/Northern Church. ${ }^{38}$

Trijntje continues her letter by switching to national news: furthermore, I do not know to write much apart from the sad war here at sea and on land. A similar switch is made in the delegated letter, in this case with the conjunction as: as it is

35 Mette Jans put a mark on the record of her marriage with Ernst Ronge, dated 26.01.1668, which was the second marriage for both bride and groom (Amsterdam City Archive).

36 Trijntje's own letter, her two delegated letters and Neeltje Jacobs autograph are all part of the LAL corpus.

37 laus deo (semper) 'praise to God always' (and its variants lous, loos, lijus, laeus, lao) features in only about $8 \%$ of the seventeenth-century letters (43 instances of 545 private letters) against $48 \%$ of the Dutch variant (see footnote 8).

38 Trijntje Cornelis and Abraham Janse Schepmoes married on 17 December 1667 and both signed their marriage record (Amsterdam City Archive). 
here such a sad time with the war of the French and the English. ${ }^{39}$ The last part of both letters is similar and mentions the French soldiers at the borders, the taking of various ships by the English, the preferable sailing route avoiding the Channel and the wish for a safe return home. The letters close with the following identical phrasings: With this I finish and recommend you in the protection of the most highest who will protect you and all of us towards bliss amen. ${ }^{40}$

Trijntje Cornelis clearly determined both the form and content of Mette Jans' letter, which is very similar to her own letter. Only Mette's remark on her husband's location and health may be attributed to her. We will see now whether Trijntje Cornelis played a less dominant role when writing for a literate friend.

\subsection{Writing for a literate friend}

Trijntje's letter for Neeltje Jacobs differs in length from the two letters we discussed above. The brief note of only 128 words shows a formulaic beginning and closing, with the message about the childbirth in between (Figure 4). Neeltje Jacobs' own writing conventions are visible in her autograph letter, dated $25 \mathrm{May}$, in which the Dutch Praise God above all opening formula and the closing greeting and recommendation formulae nothing more at this time than be heartily greeted and be recommended to the Lord in mercy occur. ${ }^{41}$ In the note, however, we find Trijntje's Latinised Laus deo formula and her closing With this I finish and recommend you in the protection of the most highest who will protect you and all of us towards bliss amen. Also in the case of her literate friend, Trijntje appears to determine the formulaic opening and closing part.

In between the opening and closing of the note, the essential message is given, introduced by the familiar phrasing I your wife Neeltje Jacobs let you know that...In nine short lines, the birth of her daughter, the difficult delivery, the fear of dying, and thankfulness for the Lord's help are presented from the perspective of Neeltje: ${ }^{42}$

39 Dutch text: vors weet Ick nijet veel te schrijven dan de droevijge orlogh hijer te water ende te lant. In the delegated letter with the conjunction want: want het Is hijer sulcke bedroefde tijt met met den orlogh van franse ende de engelse.

40 Dutch text: hijer mede eijndege ende bevele ul In de beschermijnge des alder hochste dije ul ende ons alle wijl bewaren tot salijghijt amen.

41 Dutch text: geen meer op dit pas dan sijt van haerten gegrooet en sijt den heer in genaden beh bevoolen.

42 Juriaan/Jurriaan Leenderts, who originated from Emden, and Neeltje Jacobs married on 13 June 1671. Their daughter Giertje/ Giertie was baptised on 29 May 1672 (registers of marriage and baptism of the Amsterdam City Archive). 


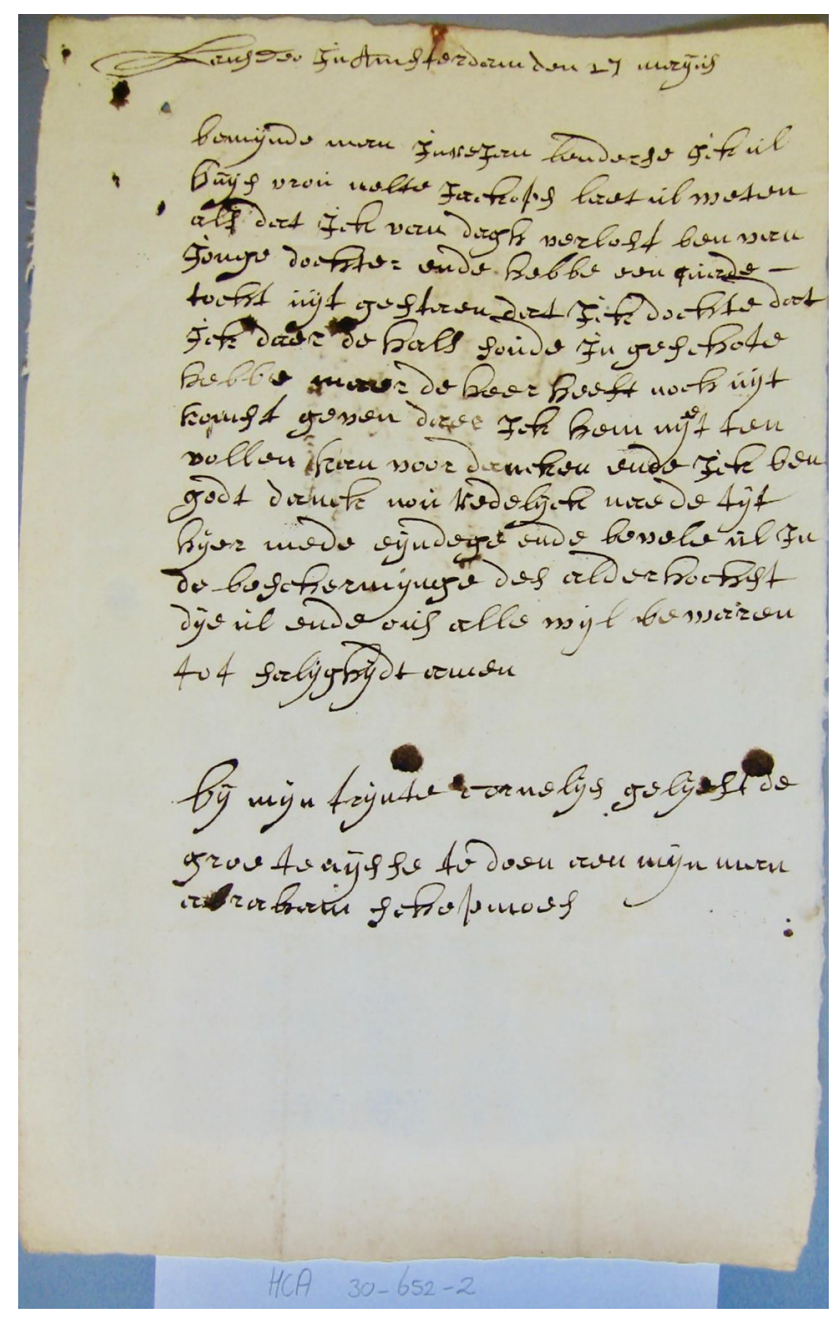

Figure 4: The brief delegated letter written by Trijntje Cornelis for Neeltje Jacobs.

(5a) 'I your wife Neeltje Jacobs let you know that today I am delivered of a young girl and [I] have experienced a bad time, that I thought that I would die, but the Lord has yet given salvation for which I cannot thank him fully enough and I am now reasonably well after all, thank God' 


\author{
Dutch original \\ ick ul huijs vrou nelte jackops laet ul weten als dat \\ ick van dagh verlost ben van \\ jonge dochter ende hebbe een quade \\ tocht uijt gestaen dat ick dochte dat \\ ick daer de hals soude in geschote \\ hebbe maer de heer heeft noch uijt \\ komst geven daer ick hem nijet ten \\ vollen kan voor danken ende ick ben \\ godt danck nou redelijck nae de tijt
}

This genuine-sounding report has to be attributed to Neeltje herself and may have been dictated. Ultimately, Trijntje Cornelis does not conceal her role as delegated writer, as the letter ends with: by me Trijntje Cornelis, be so kind and greet my husband Abraham Schepmoes. ${ }^{43}$

In sum, Trijntje Cornelis' and Mette Jans' letters show striking similarities both in form and content. Neeltje Jacobs' note is a brief report of childbirth embedded in the formulaic opening and closing. Trijntje appears to determine the formulaic part with epistolary formulae which deviate from those in Neeltje Jacobs' autograph.

\title{
7 Discussion and conclusions
}

Having examined cases of female delegated writers, did we succeed in opening the black box of delegated writing? Did we reveal the identity of the delegated writers, their relationship to the senders and their respective roles in the delegated writing process? In other words, were we able to establish the most probable scenario of Early Modern delegated writing in The Netherlands?

\subsection{Discussion}

First of all, I would like to stress that research on delegated writing is not only part of the history of literacy, but also belongs to (language) history from below, which focuses on the middle and lower ranks of society, the levels below the very highest rank that dominated (language) history for a long time (cf. Ashplant 2018; Elspaß 2012b; Lyons 2013; Rutten and van der Wal 2014: 2-5). We have to deal with often invisible delegated writers: professional writers for whom writing was part of their

43 Dutch text: bij mijn trijnte cornelijs gelijft de groetenijsse te doen aen mijn man abrabam schepmoes. 
profession and social writers who were more or less experienced writers, writing for a family member, relative, friend or colleague. For our findings and conclusions, it is important to stress that our identified delegated female writers were all social writers. Two of them, Kathelijne Haexwant and Elsje Wijbrants, belonged to the upper class and to the age group of 50 and older. The other four were 30 or younger: Trijntje Cornelis belonged to the upper-middle class, Josje Elias Verburg to the lower-middle class and Jaapje Koerten to the lower class, whereas Susanna Jans' social class is unknown (for these social class and age variables see Rutten and van der Wal 2014: 9-13). ${ }^{44}$ This means that women from all social classes below the highest rank possessed writing skills and writing experience which enabled them to function as letter writers for others. From a gender perspective we saw that these female delegated writers wrote for other women. Also in other cases of identified social writers (see Section 4), we found no gender crossing in cases of female delegated writers, whereas male delegated writers wrote for both men and women. The choice of a social writer was, and is, primarily an issue of the immediate environment and social network. Women called upon other women in their network of relatives and wives of sailing crew. Men aboard ships relied on other men and sons wrote letters for their mothers (see Section 4). Delegated writing was performed by whoever was at hand.

Lyons' research on possible scenarios of nineteenth- and early twentiethcentury delegated writing in France, Italy and Spain was mainly based on testimonies either by the delegated writers themselves or by others (Lyons 2014: 253-259). He concluded that the scribes "were for the most part not simply copyists, responding mechanically to dictation" and that "they are best seen as coauthors in a joint enterprise" (Lyons 2014: 259). For the Early Modern period in the Netherlands, very few such testimonies are available, but instead I was fortunate to have found what after analysis appeared to be autographs and delegated letters, written by the same scribe. These rare findings allowed a linguistic approach to the delegated writing process by analysing and comparing the two types of letters. After having presented the individual cases of delegated writers, it is time to conclude what results were achieved by my linguistic approach.

\subsection{Conclusions}

First of all, our quantitative research proved that non-autographs were more formulaic than autographs or, in other words, that delegated writing was highly

44 Both Elisabeth Emerij and Marretje Philipse (mentioned in Section 4) were in the age category of 30-50 and the upper-middle class. 
formulaic. Formulaic language was a safe option and convenient strategy for delegated writers. Secondly, by exploring the seventeenth-century part of the $L A L$ corpus, we were able to reveal the identity of a number of delegated writers. Thirdly, concentrating on female delegated writers in my qualitative research, I analysed their two types of letters, which gave us a view of the actual practice of delegated writing. All delegated writers appeared to rely on formulaic language, but their practice varies from writing to communicate a sign of life in a formulaic jacket, such as Kathelijne Haexwant's letter for Joosje Cornelis, to a selection of familiar formulae combined with new content and wrapped in a particular structure, such as Josje Elias Verburg's letter for Grietje Martens. ${ }^{45}$ The comparison of autographs and delegated letters clearly shows that the delegated writer chooses from her own stock of familiar formulae and other characteristics such as religious phrasings, and thus determines the style, language and structure of the letter. The similar formulae and structuring in the two types of letters excludes the scenario of the invisible sender dictating the whole letter. However, particular private information was given by the sender as indicated in the descriptions of the cases above and in some cases such as the brief note for Neeltje Jacobs, a literal quote may be assumed. Often the letters are fully written from the perspective of the senders, but in some cases the delegated writer deviates from the chosen perspective and manifests herself, as Kathelijne Haexwant and Trijntje Cornelis did.

Unlike in the case of professional writers, the close relationship between the social writers and the senders could have resulted in a kind of collaboration beyond providing private information during the writing process. This is, however, only a thought, for which we did not find any evidence. Although it remains difficult to pinpoint the role of the often-invisible sender, our findings all indicate the strong position of the delegated writer in the process, in Lyons' terminology "the power of the writer". This seems to be an obvious idea as the senders were illiterates or inexperienced writers and the scribes were the experienced letter writers. However, we even found this phenomenon in the delegated letter for Neeltje Jacobs, who was an experienced writer and only temporarily unable to write.

My linguistic approach offered insight into the practice of delegated writing and the roles of writers and senders. I established the identity of delegated writers and traced characteristics of their writing process. In other words, we have obtained a view of the female social writers at work. Our additional archival research of local registers of marriage, baptism or burial and registers of notaries

45 The delegated letters also vary in the amount of free content, depending on their senders. Some of them only communicated a sign of life, while others informed the addressee about childbirth, deaths and efforts to survive during the plague or in difficult financial circumstances. 
has revealed the social status and age of the writers, provided more information on the family news in the letters, and detailed the relationships and networks of senders and writers. In sum, our linguistic approach to the rare legacy of female delegated writers has enabled us to start opening the black box of Early Modern delegated writing in the Netherlands and to contribute to the still fragmentary history of delegated writing.

\section{References}

van Alphen, Marc. 2014. Het oorlogsschip als varend bedrijf: Schrijvers, administratie en logistiek aan boord van Nederlandse marineschepen in de 17de en 18de eeuw [The warship as sailing company: writers, administration and logistics aboard Dutch maritime vessels]. Franeker: van Wijnen.

Ashplant, Timothy G. 2018. Life writing "from below" in Europe: Introduction. The European Journal of Life Writing VII. 1-9.

Austin, Frances. 1973. Epistolary conventions in the Clift family correspondence. English Studies 54(9-22). 129-140.

Austin, Frances. 2004. Heaving this importunity: The survival of opening formulas in letters in the eighteenth and nineteenth Centuries. Historical Sociolinguistics \& Sociohistorical Linguistics 4. http://www.let.leidenuniv.nl/hsl_shl/heaving_this_importunity.htm (accessed 25 June 2020).

Blaak, Jeroen. 2009. Literacy in everyday life: Reading and writing in Early Modern Dutch diaries. Leiden \& Boston: Brill.

Brouwer, Judith. 2014. Levenstekens: Gekaapte brieven uit het rampjaar 1672. [Signs of life: captured letters in the 'year of disaster' 1672]. Hilversum: Verloren.

Elspaß, Stephan. 2005. Sprachgeschichte von unten: Untersuchungen zum geschriebenen Alltagsdeutsch im 19. Jahrhundert. Tübingen: Niemeyer.

Elspaß, Stephan. 2012a. The use of private letters and diaries in sociolinguistic investigation. In Juan Manuel Hernández-Campoy \& Juan Camilo Conde-Silvestre (eds.), The handbook of historical sociolinguistics, 156-169. Chicester: Wiley-Blackwell.

Elspaß, Stephan. 2012b. Between linguistic creativity and formulaic restriction: Cross-linguistic perspectives on nineteenth-century lower class writers' private letters. In Marina Dossena \& Gabriella Del Lungo Camiciotti (eds.), Letter writing in Late Modern Europe, 45-64. Amsterdam \& Philadephia: John Benjamins.

Frijhoff, Willem \& Marijke Spies. 1999. 1650: Bevochten eendracht [1650: hard-won unity]. Assen: Van Gorcum.

Graff, Harvey J. 1987. The legacies of literacy: Continuities and contradictions in western culture and society. Bloomington, Ind: Indiana University Press.

Houston, Robert A. 2013 [2002]. Literacy in Early Modern Europe: Culture and education 1500-1800, 2nd edn. London \& New York: Routledge.

Kuijpers, Erika. 1997. Lezen en schrijven: Onderzoek naar het alfabetiseringsniveau in zeventiende-eeuws Amsterdam [Reading and writing: research on the literacy level in seventeenthcentury Amsterdam]. Tijdschrift voor Sociale Geschiedenis 23. 490-522. 
Laitinen, Lea \& Taru Nordlund. 2012. Performing identities and interaction through epistolary formulae. In Marina Dossena \& Gabriella Del Lungo Camiciotti (eds.), Letter writing in Late Modern Europe, 65-88. Amsterdam \& Philadephia: John Benjamins.

Lyons, Martyn. 2013. The writing culture of ordinary people in Europe, c. 1860-1920. Cambridge: Cambridge University Press.

Lyons, Martyn. 2014. The power of the scribe: Delegated writing in modern Europe. European History Quarterly 44(2). 244-262.

Nevalainen, Terttu. 2001. Continental conventions in early English correspondence. In Diller Hans-Jürgen \& Manfred Görlach (eds.), Towards a history of English as a history of genre, 203-224. Heidelberg: Universitätsverlag C. Winter.

Nobels, Judith \& Marijke van der Wal. 2012. Linking words to writers: Building a reliable corpus for historical sociolinguistic research. In Nils Langer, Steffan Davies \& Wim Vandenbussche (eds.), Language and history, linguistics and historiography: Interdisciplinary approaches, 343-361. Bern etc: Lang.

Nobels, Judith. 2013. (Extra)Ordinary Letters: A view from below on seventeenth-century Dutch. Utrecht: LOT. University of Leiden Dissertation.

Poster, Carol \& Linda C. Mitchell (eds.). 2007. Letter-writing manuals and instruction from antiquity to the present: Historical and bibliographical studies. Columbia: University of South Carolina Press.

Rutten, Gijsbert \& Marijke van der Wal. 2014. Letters as Loot: A sociolinguistic approach to seventeenth-and eighteenth-century Dutch. Amsterdam \& Philadelphia: John Benjamins Publishing Company. OA.

Schneider, Edgar. 2013 [2002]. Investigating historical variation and change in written documents: New perspectives. In Jack K. Chambers \& Natalie Schilling (eds.), The handbook of language variation and change, 2nd edn., 57-81. Malden \& Oxford: Wiley-Blackwell.

van Vliet, Adri P. 2007. 'Een vriendelijcke groetenisse': Brieven van het thuisfront aan de vloot van De Ruyter (1664-1665) [A friendly greeting: letters from home to De Ruyter's fleet (1664-1665)]. Franeker: Van Wijnen.

van der Wal, Marijke. 2006. Onvoltooid verleden tijd: Witte vlekken in de taalgeschiedenis. [Imperfect past time: blank spots in language history]. Inaugural lecture 17 November 2006. Amsterdam: Koninklijke Nederlandse Academie van Wetenschappen.

van der Wal, Marijke. 2014. In gesprek met het taalverleden [Conversation with the linguistic past]. Farewell lecture 19 December 2014. Leiden: Leiden University.

van der Wal, Marijke. 2016. Goede nachten [Good nights]. In Alex Reuneker, Ronny Boogaart \& Saskia Lensink (eds.), Aries netwerk: een constructicon [Arie's network: a construction], 211-213. Leiden: Leiden University.

van der Wal, Marijke \& Gijsbert Rutten. 2013a. Variatie, conventies en verandering: Zeventiende- en achttiende-eeuwse buitgemaakte brieven onder de loep [Variation, conventions and change: seventeenth- and eighteenth-century confiscated letters examined]. Internationale Neerlandistiek 51. 122-138.

van der Wal, Marijke \& Gijsbert Rutten. 2013b. The practice of letter writing: Skills, models, and Early Modern Dutch manuals. Language \& History 56. 18-32.

van der Wal, Marijke \& Gijsbert Rutten. 2016. At the cross-roads: Orality and literacy in Early and Late Modern Dutch private letters. In Ann-Catrine Edlund, Timothy G. Ashplant \& Kuismin Anna (eds.), Reading and writing from below: Exploring the margins of modernity, 197-214. Umeå: Umeå University \& Royal Skyttean Society. 
van der Wal, Marijke, Gijsbert Rutten \& Andreas Krogull. 2018. Afscheidsgroeten diachroon: constanten en veranderingen in Nederlandse brieven (1660-1840). [Farewell greetings diachronically: constants and changes in Dutch letters (1660-1840)]. In Timothy Colleman, Johan De Caluwe, Veronique De Tier, Anne-Sophie Ghyselen, Liesbet Triest, Roxane Vandenberghe \& Ulrike Vogl (eds.), Woorden om te bewaren - Huldeboek voor Jacques Van Keymeulen [Words to keep - In honor of Jacques Van Keymeulen], 451-466. Gent: Universiteit Gent, Vakgroep Taalkunde, afdeling Nederlands.

van der Wal, Marijke, Gijsbert Rutten \& Tanja Simons. 2012. Letters as loot: Confiscated letters filling major gaps in the history of Dutch. In Marina Dossena \& Gabriella Del Lungo Camiciotti (eds.), Letter writing in Late Modern Europe, 139-161. Amsterdam \& Philadelphia: John Benjamins.

Wray, Alison. 2002. Formulaic language and the lexicon. Cambridge: Cambridge University Press.

\section{Websites}

Amsterdam City Archive online. https://archief.amsterdam/indexen/persons (accessed 25 June 2020).

The Letters as Loot/ Brieven als Buit corpus. Leiden University. Compiled by Marijke van der Wal (Programme leader), Gijsbert Rutten, Judith Nobels and Tanja Simons, with the assistance of volunteers of the Leiden-based Wikiscripta Neerlandica transcription project, and lemmatised, tagged and provided with search facilities by the Institute for Dutch Lexicology (INL). 2013; second release 2015: third release 2021. http://brievenalsbuit.ivdnt.org (accessed 9 March 2021).

Brieven als Buit-2/Letters as Loot-2, an additional collection of letters, compiled by Marijke van der Wal, Leiden University, first release 26 February 2021. http://brievenalsbuit2.ivdnt.org (accessed 9 March 2021).

The dictionaries MNW and WNT. gtb.inl.nl (accessed 25 June 2020). 